\title{
DEHB Tanısı Almış 9-10 Yaş Grubu Öğrencilerine Uygulanan Duygusal Okur-Yazarlık Programının Duygusal Zekâ ve Dikkat Becerisi Düzeyleri Üzerindeki Etkisi
}

\author{
The Effect of the Emotional Literacy Program on the Emotional Intelligence and \\ Attention Skill Levels of the 9-10 Years Old Students with ADHD
}

\author{
Emine Beyza ÖZOĞLU* \\ Müge YÜKSEL ${ }^{* *}$
}

Öz

$\mathrm{Bu}$ araştırmanın amacı DEHB tanısı almış 9-10 yaş grubu öğrencilerine uygulanan duygusal okuryazarlık programının duygusal zekâ ve dikkat becerisi düzeyleri üzerindeki etkisini araştırmaktır. Araştırmanın modeli ön test-son test eşleştirilmiş kontrol gruplu yarı deneysel desendir. Araştırmaya deney ve kontrol grubu olarak toplam 16 katılımcı dâhil edilmiştir. Bar-On Duygusal Zekâ Modeli esas alınarak araştırmacılar tarafından oluşturulan on oturumluk "Duygusal Okuryazarlık Programı” deney grubundaki 8 öğrenciye 10 hafta boyunca her oturum 120 dakika olmak üzere uygulanmış, kontrol grubuna ise müdahalede bulunulmamıştır. Araştırmaya Balıkesir ilinde bir ilkokula devam eden öğrencilerden DEHB tanısı almış 9-10 yaş çocukları katılmıştır. Araştırmaya katılan öğrencilerin dikkat becerilerini ölçmek amacıyla d2 Dikkat Testi uygulanması yapılmış, duygusal zekâ düzeylerini belirlemek amacıyla ise Bar-On Çocuklar İçin Duygusal Zekâ Ölçeği uygulanmıştır. Elde edilen veriler SPSS 15 programına girilerek Kovaryans analizi ile analiz edilmiştir. Elde edilen istatistik sonuçlarının manidarlığı 0.05 düzeyinde test edilmiştir. Bulgular, DEHB olan çocukların duygusal okuryazarlıklarını geliştirmeye yönelik uygulanan program sonucunda duygusal zekâ düzeylerinde anlamlı ölçüde etkili olduğunu gösterirken, dikkat becerileri üzerinde ise etkili olmadığı sonucuna varılmıştır. Araştırmanın sonunda, elde edilen bulgular ve araştırmanın sınırlılıkları tartışılmış, sonraki araştırma ve uygulamalara yönelik öneriler sunulmuştur.

* Psikolojik Danışman, Atatürk İlkokulu, beyzazengin10@hotmail.com

** Doç. Dr., Marmara Üniversitesi Atatürk Eğitim Fakültesi, Eğitim Bilimleri Bölümü Rehberlik ve Psikolojik Danışmanlık Bölümü, mugeyuksel@marmara.edu.tr 
Anahtar Kelimeler: Dikkat Eksikliği ve Hiperaktivite Bozukluğu, Duygusal Zekâ, Duygusal Okuryazarlık, Dikkat Becerisi

\begin{abstract}
The aim of this research is to investigate the effect of the emotional literacy program on the emotional intelligence and attentional skills of 9-10 year old students with ADHD. The model of the study was pre-test-post-test semi-experimental design with matched control group. A total of 16 participants were included in the study as experimental and control groups. Eight students in the ten-session "Emotional Literacy Program" experiment group, formed by the researchers based on the Bar-On Emotional Intelligence Model, were administered 120 minutes per session for 10 weeks and no intervention was conducted for the control group. Children aged 9-10 years who were diagnosed with ADHD from a primary school in Balikesir province participated in the research. D2 Attention Test was applied to measure attentional skills of the students participating in the research and Emotional Intelligence Scale for Bar-On Children was applied to determine emotional intelligence levels. The obtained data were analyzed by covariance analysis by entering SPSS 15 program. The significance of the obtained statistical results was tested at 0.05 level. Findings show that children with ADHD have a significant effect on levels of emotional intelligence as a result of the program implemented to improve their emotional literacy, whereas they are not effective on attention skills. At the end of the research, the findings and the limitations of the research are discussed, suggestions for the next research and applications are presented.
\end{abstract}

Keywords: Attention Deficit and Hyperactivity Disorder, Emotional Intelligence, Emotional Literacy, Attention Skill

\title{
Giriş
}

Çağdaş eğitim tanımları bireyin duygusal fiziksel ve bedensel yönden sağlıklı gelişimini konu etmektedir. İnsan biyo-psiko-sosyal bir varlıktır. Gelişim alanları perspektifinden bakıldığında tüm gelişim alanları birbiriyle ilintilidir. Bu nedenle gelişim alanlarının herhangi birindeki olumsuzluk bir diğerine yansıyabilmektedir (Yeşilyaprak, 2002). Dikkat eksikliği ve hiperaktivite bozukluğu (DEHB) da birçok gelişim alanında etkisini hissettirebilecek yapıdadır. Yavuzer (2000)'e göre DEHB olan çocuklar dikkat sürelerinin kısa olması nedeniyle çok geniş kapsamlı problemlerle karşılaşırlar özellikle öğrenme onlar için güç bir durumdur. Öğrenme güçlüğünde sadece akademik alanda değil motor, pratik beceriler ve sosyal becerilerde yetersizlik görülmektedir. DEHB tanısı alan çocuk ve ergenlerde sosyal, akademik, ailesel ve ileride iş alanlarında yetersizlikler görülmektedir (Barkley, 2003; Saydanoğlu, 2011).

DEHB olan çocukların her çeşit uyaranın etkisi altında kaldıkları görülür. Bu sebeple dersi uzun süreli takip edemezler, uyarıcılar dikkatini dağıtır, az dinler çok konuşurlar. Çoğunlukla hareketleri hızlı, değişken ve amaca yönelik olmayan türdendir. Herhangi bir hareketin sonuçlarını o hareketi yapmadan önce düşünemez ve dürtülerini engelleyemezler. Yapılmaması gerektiğini iş işten geçtikten sonra anlarlar (Soykan, 1991). Yaşamın erken dönemlerinde başlayan dikkat eksikliği ve hiperaktivite bozukluğu (DEHB) çocuğun yaşına, gelişim evresine uygun 
düşmeyen dürtü denetiminde yetersizlik, dikkatin yoğunlaştırılamaması ve aşırı hareketlilik gibi belirtilerle kendini gösteren nöropsikiyatrik bir bozukluktur (Ercan ve Aydın, 2000; Selçuk, 2000; Soykan,1991). DEHB’nin tam olarak kökenleri aydınlatılabilmiş değildir, köken olarak biyopsiko-sosyal nedenlerin ortak bir biçimde yer aldığı düşünülmektedir (Turgay, 1997). Bu sebeple hastalığın çok boyutlu izlenmesi gerekmekte giderek "psikososyal boyut” önem kazanmaktadır (Demirci, 2013).

DEHB her ne kadar bilişsel ve yürütücü işlevlerdeki bozukluklar ile tanımlansa da DEHB'li çocuk ve ergenlerde sosyal kısıtlılıklar görülür. DEHB olan çocuklar kendilerini kontrol etmeyi bilememekle birlikte enerji ve öfkelerini kanalize etme becerisinden yoksundurlar (Ercan ve Aydın, 2000). Agresif belirtileri olan DEHB'li çocuklar karşılarındaki kişilerin davranışlarını aşırı yorumlamaya meyillidirler ve uygunsuz agresif çıkışlı yanıtlar verebilirler (Bliss ve McCabe, 2011). DEHB'de görülen dürtüsellik, saldırganlık, duygu tanıma gibi ileri sosyal işlevlerde bozukluk olması empati becerileri ve sosyal ilişkileri bozucu etki yapmaktadır (Demirci, 2013). Bu çocukların davranışsal bir takım eksiklikleri sosyal bilişlerini de etkiler bu nedenle empati becerileri daha düşüktür. Hiperaktif davranış kadar DEHB'li çocuklardaki dikkatsizlik belirtileri de sosyal problemlerle sonuçlanabilir (Nijmeijer, Minderaa, Buitelaar, Mulligan, Hartman, 2008; Barkley,2003). Çocukların sağlıklı bir ruh dünyası oluşturabilmeleri için diğer insanlarla yeterli düzeyde sosyal etkileşime girebilmesi bu beceriye etkili düzeyde kullanabilmesi gerekmektedir. Sosyal bilişsel becerilerin gelişimi erken dönemde önemsenmez ise kişilerin sosyal, iletişimsel yetersizliklerine neden olmaktadır. Bu yetersizlikler DEHB'li bireylerde görülebilmektedir. DEHB'li bireylerin karşısındaki kişilerin duygularını anlamalarında, yeterli sosyal etkileşimde bulunmalarında sorunlar olabilir. Daha az arkadaş sahibi olmaları ve uzun süre arkadaşlıklarını sürdürmede yetersizliklerinin olması ve buna bağlı olarak aile, okul ve iş yaşantılarında bozulmaların olduğu bilinmektedir Bu nedenle empati becerilerini içine alan, sosyal bilişsel becerilerdeki yetersizliklerin farkında olmak ve DEHB tedavisinde bu konu üzerine de odaklanmak, DEHB’li kişilerin yaşam kalitesini arttıracak ve ileride eşlik edebilecek problemlerin ortaya çıkma olasılığını da azaltacaktır (Gümütaş,2011).

Duygusal ve sosyal becerileri yüksek düzeyde olan çocuklar, kaygı, stres, öfke gibi zor duygular ile etkili şekilde baş edebilir. Zor ve güçlü duygularla başa çıabilme becerisi, öğrencide öz-bilinç, öz-kontrol, öz-düzenleme becerilerinin gelişmesini sağlar. Kendi davranışlarını yönetebileceğine ve yapacağı davranıştan etkili sonuç alacağına ilişkin beklenti, beraberinde motivasyonu getirir. Kendini ve başkalarını sevme yeteneği kazanan çocuk yeterli düzeydeki motivasyon ile akademik başarısını ve iyi oluş düzeyini artırır (Goleman,1996; Mayer \& Salovey 1995; Steiner, 2003). Duygusal zekâ puanı daha yüksek olan öğrenciler, kendi duygularını anlama, başkalarının duygularını fark etme, diğerleriyle ilişkilerini yönetebilme, problemlerini etkili biçimde çözme, dürtülerini kontrol edebilme ve stresle başa çıkabilme becerileri alanlarında duygusal zekâ puanı düşük olan öğrencilere göre daha iyidir (Hafızoğlu, 2007; Göçet, 2006).

Bebeklikten itibaren, her gelişim döneminde çocuğun özelliğine ve DEHB'in derecesine göre farklı şekillerde kendini gösteren bu durum okul çağı çocuklarını hem akademik 
hem de sosyal ilişkiler bağlamında zorlamaktadır. Özellikle son çocukluk dönemi olarak adlandırılan ilkokul dönemindeki çocuklarda artık bu durum iyice belirginleşmiş, ailenin, okulun ve sosyal çevrenin dikkatini olumsuz yönde etkilemeye başlamıştır. Son çocukluk dönemi içerisinde yer alan çalışma grubumuzun gerçekleştirmesi gereken gelişim görevleri sahip oldukları DEHB nedeniyle sekteye uğramaktadır. DEHB tanısı konan çocuklar, ergenlik dönemine dürtüsellik, kolay öfkelenme gibi belirtilerle girerlerse, bunlar ergenliğin kendine özgü davranışları ile birleştiğinde kimlik bocalaması ve diğer davranışsal sorunların çözümü daha da güçleşebilmektedir (Öztürk, 2004). Risk faktörleri düşünüldüğünde ergenlik dönemi öncesi son çocukluk dönemi DEHB’in etkilerini azaltmak için bir fırsattır. Kanay (2006), Türe (2010), Saydanoğlu (2011), Gümütaş (2011), Bliss ve McCabe (2011) DEHB olan ilköğretim öğrencilerinde uyumsal davranış, benlik kavramının akademik başarılar ile olan ilişkileri, öfke ve saldırganlık düzeyleri, empatik davranma ile ilgili çalışmalar yapmıştır. DEHB olan çocukların olmayanlara göre uyumsal davranışları az, benlik algıları olumsuz, akademik başarıları düşük, öfke ve saldırganlık düzeyleri fazla, empatik davranma düzeyleri de az bulunmuştur. Literatürle uyumlu bu çalışmaların yanında DEHB olan çocuklarda duygusal zekâ ve sosyal becerilerin değerlendirildiği Büyükaslan (2015)'nın çalışmasında DEHB olmayan çocuklara göre duygusal zekâ düzeyleri düşük bulunmuştur. Bu çocuklarla yapılacak olan psikoeğitsel müdahalenin duygusal gelişim alanında olumlu etki yaratacağı düşünülmektedir. Öztürk Şahin ve Tuğlu (2010) tarafından yapılan makale çalışmasında DEHB’in sadece bireyi değil ailesini ve çevresini de etkilediği ergenlerde bu bozukluğun madde kullanımı, yasal sorunlar, olumsuz akran ilişkisi, güven eksikliği, okul ve iş başarısızlığı olarak birlikte görülebileceğine değinilmiş, bireyin önündeki bu engelini kaldırdıktan sonra daha sağlıklı devam edebileceği aktarılmıştır. Bireyin bu engeli kaldırabilmesi için yapılan araştırmalardan da yola çıkılarak eğitim programlarının faydalı olabileceği akla gelmektedir. Ayrıca sosyal hayatta da etkisi düşünüldüğü bireyin güven, akran ilişkisi gibi olumsuz durumları nedeniyle araştırmamızın bu iki konunun üzerinde yoğunlaştırılması ihtiyacı hissedilmiştir. Ulutaş (2005) doktora tezinde anasınıfına devam eden altı yaş çocuklarının duygusal zekâlarına duygusal zekâ eğitiminin etkisini incelemiştir. Deney, placebo ve kontrol grubu ile yapılan araştırmada deney grubundaki çocukların duygusal zekâlarında anlamlı düzeyde farklılık olduğunu saptamıştır. Vardığı sonuçlardan biri ise araştırmamızın temellerinden biri olan akademik zekâyı da destekleyen eğitim programlarına duygusal zekâ etkinliklerini ekleyerek duyguları tanıma, anlama gibi kazanımlara ulaşılabilmesini sağlamaktır. Bahsedilen gerekçelerle beraber, gelişim sürecinde herhangi bir gelişimsel alanda meydana gelen değişim diğer alanları da etkiler ilkesinden yola çıkarak, bu çalışma ile ilkokul çocuklarının sosyal duygusal gelişim alanlarını desteklemeye yönelik bir duygusal okur-yazarlık programı geliştirilmiştir. Bu programın, ilkokul çocuklarının hem dikkat becerisi hem de duygusal zekâları üzerindeki değişimi etkilemesi beklenmiştir. Bu bağlamda araştırmanın problem cümlesi; "DEHB tanısı almış 9-10 yaş grubundaki çocuklara yönelik duygusal okur-yazarlık programının geliştirilmesi, geliştirilen programın duygusal zekâ düzeyleri ve dikkat becerisi üzerindeki etkisinin sınanması"dır. 
Araştırmanın genel amacına bağlı olarak nicel veriler aracılığıyla test edilen araştırma denencesi aşağıda belirtilmiştir.

- Ön test puanlarının etkisi kontrol edildikten sonra duygusal okuryazarlık programı uygulanan deney grubunda yer alan katılımcıların duygusal zekâ ve dikkat son test puanları kontrol grubunda yer alan katılımcıların son test puanlarından daha yüksektir.

\section{Yöntem}

\section{Araştırma Modeli ve Çalışma Grubu}

Araştırmada 9-10 yaş ilkokul öğrencileri için geliştirilmiş olan duygusal okur-yazarlık programının duygusal zekâ ve dikkat becerisi üzerindeki etkisi nicel araştırma yöntemlerinden olan ön test-son test eşleştirilmiş kontrol gruplu yarı deneysel desen ile test edilmiştir. Araştırmanın bir bağımsız değişkeni iki bağımlı değişkeni vardır. Bağımsız değişken geliştirilmiş olan duygusal okuryazarlık geliştirme programıyken, bağımlı değişkenler duygusal zekâ düzeyi ve dikkat toplama becerisidir. Bu bağımlı değişkenlere ilişkin ölçme araçları uygulanan program öncesi ön test ve program tamamlandıktan sonra son test olarak uygulanmıştır. Deney grubuna program uygulanmış; kontrol grubuna ise herhangi bir uygulama yapılmamıştır.

Araştırmanın çalışma grubu Balıkesir ilinde bulunan farklı sosyo ekonomik çevrelerden alım yapan bir ilkokula kayıtlı olan 3. ve 4. sınıfa devam eden Çocuk ve Ergen Psikiyatrisi tarafından DEHB tanısı konmuş olan öğrencilerden oluşturulmuştur. Araştırmanın deney ve kontrol gruplarında yer alan bireyler rastgele belirlenemediğinden yarı deneysel desene uygun olarak eşleştirilmiş 2 grup olacak şekilde belirlenen toplam 16 çocuk iki gruba ayrılmış, böylece her bir grup 8 çocuktan oluşturulmuştur.

\section{Veri Toplama Araçları}

Bar-on duygusal zekâ ölçeği-çocuk ve ergen formu (DZÖ): Test 2000 yılında "Reuven Bar-On ve James D.A. Parker tarafından geliştirilmiştir. Ölçek, Bar-On’un duygusal ve sosyal zekâ modeli üzerine temellendirilmiştir. Geçerlik güvenirlik çalışmasını ise Köksal (2007) yapmış olup, ölçeğin Cronbach Alfa güvenirlik katsayısı 0.912 olarak hesaplamıştır. Uygulama alanı 7-18 yaşları arasındaki çocuk ve gençlere yöneliktir. Toplam 60 maddeden oluşan bir kâğıt kalem testidir.

d2 Testi: Seçici dikkati ölçen test 1981 yılında Brickenkamp tarafından geliştirilmiştir. d2 Dikkat Testi’nin 9-10 yaş öğrencileri için geçerlik güvenirlik çalışmasını ise Yaycı (2013) alana kazandırmış olup, d2’nin test tekrar test güvenirliğini .92 olarak bulmuştur.

\section{“Duygusal Okuryazarlık Programı”}

Araştırmacılar tarafından hazırlanan grup programının etkililiğini sınamak için deney grubuyla duygusal okuryazarlığı geliştirme amaçlı çeşitli etkinlik ve oyunların kullanıldığ grup çalışması planlanmıştır. Bu çalışma Reuven Bar-On Duygusal Zekâ Modeli esas alınarak duygusal okur-yazarlık geliştirmeye dönük bilişsel davranıçı kurama dayalı 10 oturumluk 
program olarak hazırlanmıştır. Bar-On’a göre duygusal zekâ olarak ortalamanın üstünde olan kişiler tehditlerde daha dirençli ve başa çıkma konusunda daha iyidirler. Eğer birey yeterli düzeyde olmayan duygusal zekâya sahip ise başarısızlık ve problemler oluşabilir (Özdemir, 2015). $\mathrm{Bu}$ modelde beş ana boyut vardır ve duygusal zekâ kişisel, kişiler arası, uyum, stres yönetimi ve genel ruh halinden oluşmaktadır (Ak Sütlü, 2013).

“Duygusal Okuryazarlık Programı”nın oluşturulması esnasında literatürde yer alan özbilinç, duyguları idare edebilmek, kendini harekete geçirmek, başkalarının duygularını anlamak, ilişkileri yönetebilmek, sorumluluk almak, olumlu benlik gelişimi, etkili dinleme becerisi, karar verme, dikkat geliştirme, işbirliği yapma, stresle başa çıkma grup programları üzerinde durulmuştur. Grup programının hazırlanması için detaylı literatür taraması yapılmış, benzer grup çalışmaları amaç ve yöntemleri incelenmiştir.

Geliştirilen programın genel amacı katılımcıların duygusal okuryazarlıklarını geliștirmek bu yolla duygusal zekâ düzeylerini ve dikkat becerilerini arttırmaktır. Oluşturulan grup programının amaçları aşağıda yer aldığı gibidir:

Kişisel ilgilerini, yeteneklerini, güçlü ve zayıf yönlerini tanırlar.

Kişisel ilgi alanlarını, yeteneklerini ve kişisel potansiyellerini tanırlar.

Şimdiki zamana odaklanma, “şimdi ve burada” kalabilme becerisi geliştirirler.

Dikkati yönlendirme ve odaklanma becerilerini geliştirirler.

Kendilerine karşı olumlu bir tutum geliştirirler.

Kendilerinin ve başka insanların olumlu özelliklerinin farkında olurlar.

Sorumluluk almaya gönüllü olurlar.

Çeşitli duyguları tanımlayacak ve ilgili olduğu sözcüklerle birleştirirler.

Duruma uygun duyguları seçerler.

Öfkeyi uygun şekilde kontrol etme ya da başa çıkmanın yollarını öğrenirler.

Sözsüz mesajları fark etmeyi öğrenirler.

Dikkatli dinleme ve konuşma becerilerini sergilerler.

Sözlü ya da sözsüz ipuçlarına dayanarak duyguları tanırlar.

Olaylar ve duygusal tepkiler arasındaki ilişkiyi açıklarlar.

Başkalarının duygularını anlayacak ve tanımlarlar.

Problem çözmede kullanılabilecek temel stratejileri öğrenirler.

Karar verme durumunda kullanılabilecek seçenekleri ya da alternatifleri tanırlar.

Başkalarıyla işbirliği yapmanın önemini öğrenirler.

Gevşeme için derin nefes alarak alıştırma yaparlar.

Kendi kendimize söylediklerimizin duygular ve performans üzerindeki etkilerini öğrenirler. 
Aşağıda araştırma için geliştirilmiş olan grup oturumlarının başlıkları ve amaçları yer almaktadır.

Çizelge 1. Duygusal okuryazarlık psikoeğitim programı oturum planı

\begin{tabular}{|l|l|l|}
\hline & Oturum bașlıkları & Genel oturum amaçları \\
\hline 1 & Tanış Benimle & $\begin{array}{l}\text { Çalışma için zemin oluşturma, amaçları ifade etme, kişisel ilgilerini, } \\
\text { yeteneklerini, güçlü ve zayıf yönlerini tanıma. }\end{array}$ \\
\hline 2 & Öz farkındalık & Kendilerinin ve yaşantılarının yönünü tanımlama, kendini tanıma. \\
\hline 3 & Benliğimi Geliştiriyorum & $\begin{array}{l}\text { Kendilerine karşı olumlu bir tutum geliştirme, kendilerinin ve başka } \\
\text { insanların olumlu özelliklerinin farkında olma. }\end{array}$ \\
\hline 4 & Sorumluluk Alıyorum & $\begin{array}{l}\text { Sorumluluğu ve sorumlu davranışı tanımlama, ellerinden gelenin en } \\
\text { iyisini yaptıklarında neler olduğunu tanımlama. }\end{array}$ \\
\hline 5 & Duygularımı Yönetiyorum & $\begin{array}{l}\text { Duygularını ifade eden çeşitli sözcükleri ve anlamlarını tanımlama, } \\
\text { değișen durumlar karşısında yaşadığı duyguları tanıma. }\end{array}$ \\
\hline 6 & Dinliyorum, Anlıyorum & $\begin{array}{l}\text { Sözsüz mesajları fark etmeyi öğrenme, dikkatli dinleme ve konuşma } \\
\text { becerilerini sergileme. }\end{array}$ \\
\hline 7 & Empatik Davranıyorum & Başkalarının duygularını anlama ve tanımlama \\
\hline 8 & Karar Verebiliyorum & $\begin{array}{l}\text { Karar verme durumunda kullanılabilecek seçenekleri ya da } \\
\text { alternatifleri tanımlama. }\end{array}$ \\
\hline 9 & Grupla Çalıșıyorum ve İșbirliği Yapıyorum & Bașkalarıyla ișbirliği yapmanın önemini öğrenme. \\
\hline 10 & Stresle Başa Çıkıyorum & $\begin{array}{l}\text { Kendi kendine konuşmanın stres üzerindeki olumlu etkilerini } \\
\text { öğrenme, gevșeme egzersizi yapma. }\end{array}$ \\
\hline
\end{tabular}

\section{Uygulama Süreci}

Deney grubuna on hafta süreyle haftada bir gün 120 dakikalık oturumlar şeklinde duygusal okuryazarlığı geliştirmeye yönelik olarak kişisel gelişim yönelimli grup çalışması uygulanmıştır. Kontrol grubu ile hiç bir çalışma gerçekleştirilmemiştir.

\section{Verilerin Çözümlenmesi ve Yorumlanması}

Yapılan grup çalışmasından önce deney ve kontrol gruplarının "Bar-On Duygusal Zekâ Ölçeği”nin ölçtüğü duygusal zekâ düzeyleri açısından birbirlerine denk gruplar olması için rastgele katılımcı seçimi yapılmış fakat çalışma grubuna katılan öğrencilerin tanı almış olan spesifik bir gruptan oluşması ve çalışma grubundaki öğrenci sayısının az olması grupların eşitlenememesine neden olmuştur. Gruplar bir sebepten dolayı eşit değilse bunları eşitlemek amacıyla Kovaryans Analizi kullanılmaktadır (Büyüköztürk, 2007). Böyle bir durumda, karıştırıcı değișken olan ön test puanlarının etkisinden arındırılarak son test puanları son test puanları arasındaki farka bakılmış ve bu amaçla Kovaryans Analizi kullanılmıştır.

\section{Bulgular}

\section{I.Araştırmaya Katılan Öğrencilerin Deney ve Kontrol Grubu Duygusal Zekâ Düzeyi Ön- son Test Puanlarına iiişkin Bulgular}

Faktörlerden biri tekrarlı ölçümler (ön-test, son-test) diğeri de farklı gruplar (deney ve kontrol) arasındaki farklılıkları belirlemek üzere veri analizinde kovaryans analizi (ANCOVA) uygulanmış ve sonuçları aşağıda verilmiştir. 
Tablo I.I.

Duygusal zekâ ölçeği son-test puanları için betimsel değerler

\begin{tabular}{cccc}
\hline Gruplar & $\overline{\boldsymbol{x}}$ & ss & N \\
\hline Deney & 192,25 & 16,60 & 8 \\
Kontrol & 143,37 & 21,58 & 8 \\
Toplam & 167,81 & 31,35 & 16 \\
\hline
\end{tabular}

Tablo 1.1.de görüldüğü gibi, duygusal zekâ ölçeği deney grubunun puanlarının aritmetik ortalamas1 $\overline{\mathrm{x}}=192,25$; standart sapmas1 ss=16,60 olarak; kontrol grubunun aritmetik ortalamas1 $\overline{\boldsymbol{x}}$ $=143,37$; standart sapması ss=21,58 olarak hesaplanmıştır. Öte yandan Levene analizi sonucunda da varyansların homojen $\left(L_{\mathrm{F}}=1,178 ; p>, 05\right)$ olduğu saptanmıştır. Bu değerler verilerin ANCOVA için yeterli koşulları sağladığını ortaya koymaktadır.

Tablo I.2.

Grupların duygusal zekâ ön-test puanlarına göre düzeltilmiş son-test puanlarının kovaryans sonuçları

\begin{tabular}{ccccccc}
\hline Varyans Kaynağ & Kareler Top. & sd & Kareler Ort. & F & p & $\mathbf{N}^{2}$ \\
\hline Model & 11803,84 & 3 & 3934,61 & 12,57 &, 000 &, 574 \\
Öntest & 1092,78 & 1 & 1092,78 & 3,49 &, 072 &, 111 \\
Gruplar & 8679,03 & 1 & 8679,03 & 27,73 &, 000 &, 498 \\
Hata & 8761,12 & 28 & 312,89 & & & \\
Toplam & 860049,00 & 32 & & & & \\
\hline
\end{tabular}

Tablo 1.2.'de görüldüğü üzere, ön-teste göre düzeltilmiş son-test ortalama puanlarının deney grubunda kontrol grubunun ortalamalarından yüksek olduğu görülmektedir. Eta kare değerleri incelendiğinde ise farklı işlem gruplarında olmanın, ön-test puanlarından bağımsız olarak son-test puanlarındaki değişkenliğin \%49'unu açıkladığı görülmektedir. Öte yandan öntest puanlarının son-test puanlarının önemli bir yordayıcısı olmadığ $\left(F_{(2,20)}=3,49 ; p>, 05\right)$ ve tek başına son test puanlarındaki değişmenin \%11'ini açıkladığı görülmektedir. Bu durumda aradan geçen zamanda diliminde deney grubuna uygulanan psikoeğitim uygulamalarının diğer değişken (zaman) olmaksızın deney grubundaki değişimin \% 49’unu açıkladığı görülmektedir. Öntest puanlarının ve grup değişkenlerinin birlikte sontest puanlarındaki değişkenliği açıklama yüzdesi \%57'dir ve bunu tanımlayan ANCOVA modelinin anlamlı olduğu görülmektedir $\left(F_{(3,}\right.$ 20) $=12,57 ; p<, 001)$. 
Tablo I.3.

Grupların duygusal zekâ ön-test puanlarına göre düzeltilmiş son-test puanlarının kovaryans sonuç grafiği

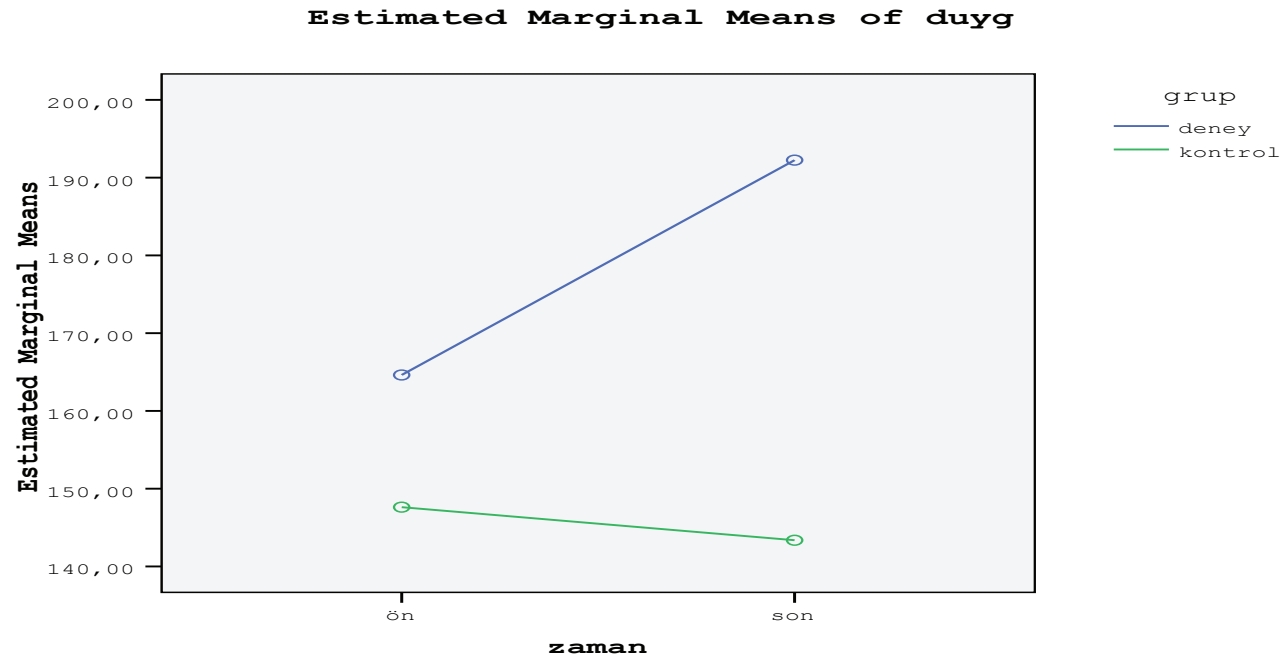

\section{Araştırmaya Katılan Öğrencilerin Deney ve Kontrol Grubu Dikkat Becerileri d2 Testi Ön-son Test Puanlarına Ilişskin Bulgular}

Faktörlerden biri tekrarlı ölçümler (öntest, sontest) diğeri de farklı gruplar (deney ve kontrol) arasındaki farklılıkları belirlemek üzere veri analizinde kovaryans analizi (ANCOVA) uygulanmış ve sonuçları aşağıda verilmiştir.

Tablo 2.I.

d2 Dikkat becerileri ölçeği son-test puanları için betimsel değerler

\begin{tabular}{cccc}
\hline Gruplar & $\overline{\boldsymbol{x}}$ & ss & N \\
\hline Deney & 313,75 & 83,91 & 8 \\
Kontrol & 279,62 & 67,98 & 8 \\
Toplam & 296,68 & 75,84 & 16 \\
\hline
\end{tabular}

Tablo 2.1'de görüleceği üzere, d2 dikkat becerileri ölçeği deney grubunun puanlarının aritmetik ortalamas $\overline{\mathrm{x}}=313,75$; standart sapmas1 ss=83,91 olarak; kontrol grubunun aritmetik ortalaması $\overline{\boldsymbol{x}}=279,62$; standart sapması ss=67,98 olarak hesaplanmıştır. Öte yandan Levene analizi sonucunda da varyansların homojen $\left(L_{\mathrm{F}}=1,042 ; p>, 05\right)$ olduğu saptanmıştır. Bu değerler verilerin ANCOVA için yeterli koşulları sağladığını ortaya koymaktadır. 
Tablo 2.2.

Grupların d2 dikkat becerileri ön-test puanlarına göre düzeltilmiş son-test puanlarının kovaryans sonuçları

\begin{tabular}{ccccccc}
\hline Varyans Kaynağ1 & Kareler Top. & sd & Kareler Ort. & F & p & $\mathbf{N}^{2}$ \\
\hline Model & 27588,62 & 3 & 9196,20 & 1,45 &, 248 &, 135 \\
Öntest & 20200,50 & 1 & 20200,50 & 3,20 &, 084 &, 103 \\
Gruplar & 128,00 & 1 & 128,00 &, 020 &, 888 &, 001 \\
Hata & 176751,25 & 28 & 6312,54 & & & \\
Toplam & 2564218,00 & 32 & & & & \\
\hline
\end{tabular}

Tablo 2.2.de görüleceği üzere ön-teste göre düzeltilmiş son-test ortalama puanlarının deney grubunda kontrol gurubunun ortalamalarından yüksek olduğu görülmektedir. Eta kare değerleri incelendiğinde ise farklı işlem gruplarında olmanın, ön-test puanlarından bağımsız olarak sontest puanlarındaki değişkenliğin yalnızca \% 01'ini açıkladığ 1 görülmektedir. Öte yandan öntest puanlarının son-test puanlarının daha önemli bir yordayıcısı olduğu $\left(F_{(2,20)}=3,20 ; p>, 05\right)$ ve tek başına son-test puanlarındaki değişmenin \%10’unu açıkladığı görülmektedir. Bu durumda aradan geçen zamanda diliminde deney grubuna uygulanan psikoeğitim uygulamalarının diğer değişken (zaman) olmaksızın deney grubundaki değişimin \% 1'den daha düşük bir oranı açıkladığı görülmektedir. Ön-test puanlarının ve grup değişkenlerinin birlikte son-test puanlarındaki değişkenliği açıklama yüzdesi ise \%13’tür ve bunu tanımlayan ANCOVA modelinin anlamlı olmadı̆̆ görülmektedir $\left(F_{(3,20)}=1,45 ; p>, 001\right)$.

Tablo 2.3.

Grupların dikkat becerisi ön-test puanlarına göre düzeltilmiş son-test puanlarının kovaryans sonuç grafiği

Estimated Marginal Means of TNE

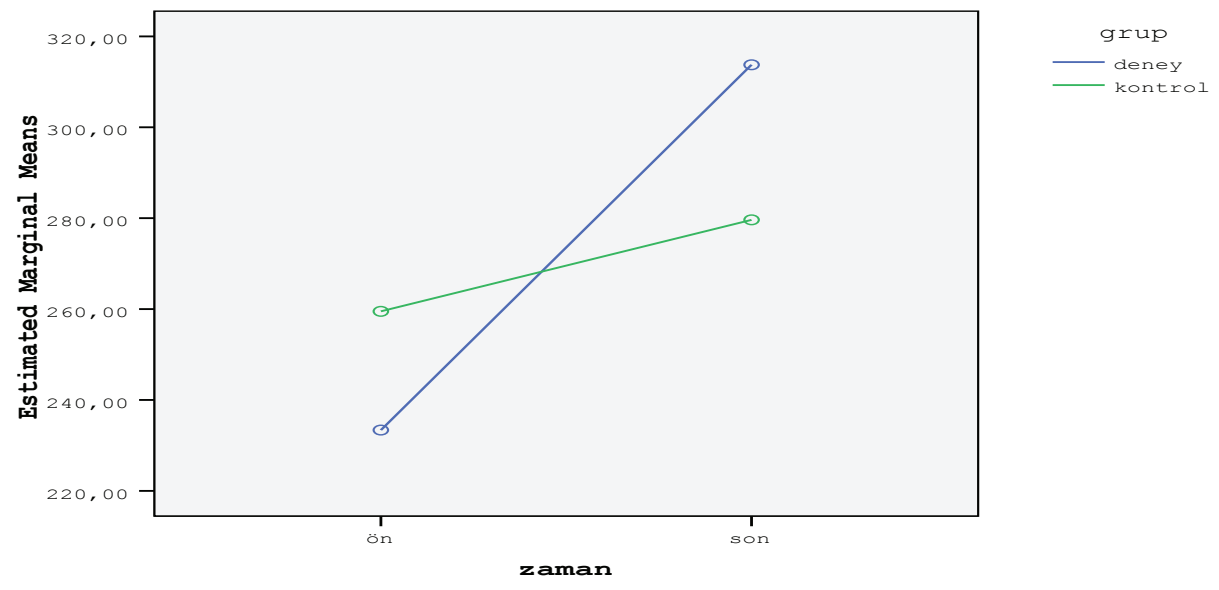




\section{Tartışma}

$\mathrm{Bu}$ araştırmada temel olarak araştırmacılar tarafindan geliştirilen duygusal okuryazarlık programının deneysel grupta yer alan katılımcıların duygusal zekâ düzeyleri ve dikkat becerileri üzerindeki etkisi araştırılmıştır. Yukarıda yer alan bulgulardan da anlaşılacağı üzere geliştirilmiş olan programın katılımcıların duygusal zekâ düzeyleri üzerinde pozitif yönde bir etkisi olmasına rağmen dikkat becerileri üzerinde bir etkisi görülmemektedir. Duygusal zekâ üzerinde yapılan araştırmalar incelendiğinde analiz sonuçlarının bilimsel alan yazınla örtüştüğü düşünülmektedir. Özdemir (2003), yaratıcı drama uygulamasının duygusal zekâ gelişimine etkisini araştırdığı çalışmasında deney grubuna katılan öğrencilerin özbilinç, empati,sosyal beceriler alt boyutlarında ve toplam duygusal zekâ puanlarında kontrol grubundaki öğrencilere göre anlamlı düzeyde artış bulunmuştur. Yurdakavuştu (2012) ilköğretim öğrencilerinin sosyal beceri ve duygusal zekâ düzeyleri üzerinde yaptığı araştırmasında sosyal beceriler ile duygusal zekâ arasında pozitif düzeyde anlamlı bir ilişki olduğunu tespit etmiştir. Freshman ve Rubino (2002) yaptıkları çalışmada duygusal zekânın IQ'den farklı bir yapı olarak değişken olabildiğini, bireylere yönelik farkındalık düzeyini artırıcı bir takım eğitsel ya da sosyalleşmeye yönelik çalışmaların kişilerin duygusal zekâ düzeylerini arttırdığını ifade etmektedirler. Zampetakis, Beldekos ve Moustakis (2009)'da yaptıkları çalışmada duygusal zekânın geliştirilebileceği, bireylerin verimliliğini diğer insanlar arasındaki rolünün verimliliğini arttırdığını ifade etmektedirler. Yaşarsoy (2006) yılında yaptığı çalışmada duygusal zekâ gelişim programının, zihinsel engelli öğrencilerin davranış bozuklukları üzerindeki etkisini incelemiştir. Sonuçlar göstermiştir ki eğitilebilir zihinsel engelli öğrencilerde duygusal zekâyı arttırmaya yönelik çalışmalar pozitif sonuç vermekle birlikte duygusal zekâsı gelişen çocukların problemli davranışlarında hem niteliksel hem de niceliksel bir azalma olmaktadır. Ergin ve Özgürol (2011) gelişen duygusal zekâ ile birlikte bilimsel düşünmenin önünde engel olabilen bir takım düşünsel engellerinde daha rahat aşılabildiğini belirtmektedirler. Sahip olunan duygular, sadece bireye ait ve özeldir. Onlar hakkında, bireyden başka kimse bilgi sahibi olamamaktadır. Duygusal zekânın değişimi, doğuştan getirilen özelliklerle ilişkili olmakla beraber duygusal zekânın seyrini, geleceğini ve gelişimini çevre, eğitim ve bireylerin deneyimi daha çok belirlemektedir (Konrad ve Hendl, 2001). Geliştirdikleri eğitim etkinlikleri ile duygusal zekânın değişimini inceleyen birçok bilim adamı duygusal zekânın her yaşta her zaman geliştirilebilen, eğitilebilen önemli bir zekâ alanı olduğunu belirtmektedirler (Shapiro 1998; Goleman 2000; Kaplan 2002; Ulutaş 2005; Hamarta, Deniz ve Saltali 2009; Konrad ve Hendl, 2001; Zampetakis, Beldekos ve Moustakis 2009). Yapılan bilimsel çalışmalar incelendiğinde çalışmamızda ulaştığımız sonuçların tutarlılık gösterdiği görülmektedir.

Araştırmamıza konu olan diğer bir önemli soru da grup çalışmasının katılımcıların dikkat becerileri üzerindeki etkisine yöneliktir. Yapılan analizlerde kovaryans sonuçlarına göre katılımcılardan deney grubuna uygulanan programın katılımcıların dikkat becerileri üzerinde bir etkisinin olmadığı görülmektedir. Dikkat gelişimi zamana bağlı bir süreç olduğu için sadece grup çalışması içerisinde yapılan dikkat çalışmalarının tanı almış çocukların dikkat becerilerini istatistiksel manada değiştirmesi güç olabilir. Ancak istatistiksel açıdan analizlere yansımasa da son test uygulamalarında ön test puanlarına göre puan ortalamalarının yüksek olduğu 
gözlenmiştir. Analizlerde programın uygulandığı grubun dikkat becerilerinde artış olmaması, dikkat becerilerini ölçmek için kullanılan d2 testinin dikkatin yalnızca seçici dikkat ile ilgili olan alanını ölçmesinin sonucu olduğu düşünülmektedir. Literatürde araştırmanın dikkat becerisi ile ilgili sonuçlarıyla uyuşmayan, dikkat becerisinin duygusal zekâ ile ilişkisi olduğunu gösteren bazı çalışma sonuçlarına rastlanmıştır.

Ergin ve Köksal (2007)'de bilişsel işlevler ile duygusal zekâ özellikleri arasındaki ilişkiyi araştırmışlar ve bilişsel işlevleri PASS teorisine dayalı olan CAS (Cognitive Assessment System) ile denetlemişlerdir. Araştırmamızla aynı Duygusal Zeka ölçeğini kullanan bu çalışmanın sonucunda uyarılma, konsantrasyon, önemli ve temel noktaya odaklanma, seçici olma, dikkatteki devamlılık vb gibi temel bileşenlerden oluşan ve dikkat olarak tanımlanan bilişsel süreç, Bar-On duygusal zeka ölçeğinde birden çok alanla ilişkili bulunmuştur. Dikkat olarak tanımlanan bilişsel sürecin duygusal zekânın temel yapısını oluşturan bu kadar yaygın bileşenlerle ilişkili olması önemli bir bulgudur. Das, Naglieri ve Kirby (1994) dikkatin hem etkileyen hem de etkilenen bir bilişsel süreç olduğu tanımlamasını doğrular bir bulgu olarak düşünülebilir. Ayrıca Bar-On (2006)'un duygusal zeka modelinin tüm alt boyutlarında yeterli olabilmek için belli oranda dikkat, konsantrasyon ve dikkatte devamlılık gerekmektedir. d2 dikkat testi sadece dikkatin seçiçi olma özelliğini denetlerken, CAS uyarılma, konsantrasyon, önemli ve temel noktaya odaklanma, seçici olma, dikkatteki devamlılık özelliklerini denetler. Yapılan analizlerde Duygusal Okuryazarlık Programının uygulandığı grubun d2 dikkat testininin ölçtügü alan olan seçici dikkati arttırmamış olması dikkatin sadece bir alanını ölçtügü için olabilir. Çünkü Ergin ve Köksal (2007) CAS ile dikkati daha genel olarak ölçmüş ve duygusal zeka arasındaki ilişkiyi anlamlı bulmuşlardır. Literatürde DEHB’ye sahip çocukların DEHB’ye sahip olmayan çocuklara göre daha düşük sosyal beceri ve duygusal zekâ alanlarında performans gösterdiğini bulgulayan çalışmalara rastlanmıştır (Befera ve Barkley 1985; Kaidar, Wiener ve Tannock 2003; Cunningham ve Barkley 1979, Frankel ve ark. 1997; Roizen, Blondis, Irwin ve Stein 1994). Arslanoğlu (2008), tarafından dikkat eksikliği/hiperaktivite bozukluğu olan erkek çocukların sosyal beceri gelişimleri ve algıladıkları yaşam kaliteleri arasındaki ilişkinin araştırıldığı çalışmanın sonuçlarına göre DEHB’ye sahip olan erkek çocukların sosyal beceri gelişimleri öğretmenleri tarafından değerlendirildiğinde düşük düzeyde olduğu aileleri tarafından değerlendirildiğinde ise orta düzeyde olduğu sonucuna varmıştır. d2 dikkat testi ile öğretmen görüşlerinin değerlendirildiği d2 geçerlik güvenirlik çalışmasında öğretmenlerden dayanıklı, motivasyonu yüksek ve sebatlı olan ve dayanıklı olmayan kolay pes eden eden üçer öğrenciyi yazmaları istenmiştir. Bu öğrencilere uygulanan d2 dikkat testi sonuçları karşılaştırıldığında dayanıklı ve motivasyonu yüksek öğrencilerin sabırlı olabildikleri için sürdürme becerileri sayesinde d2 test performansının, dayanıklı olmayan öğrencilere göre daha yüksek olduğu saptanmıştır (Yayc1, 2013). Bu dayanıklılık ve sebatlık motivasyon gerektirdiğinden duygusal zeka ile de ilintilidir. Alan yazınında dikkat becerisini eğitim yoluyla arttırılabileceğini gösteren çalışmalar bulunmaktadır. Tunca (1981) ve Özmen (2006) öğrencilerin dikkat becerilerinin gelişime açı olduğunu, geliştirilecek materyallerle desteklenen öğrencilerin dikkat düzeylerinin önemli ölçüde arttırılabileceğini aktarmaktadır. 
Özetle yapılan çalışmanın neticesinde, 9-10 yaş arası çocuklar için geliştirilmiş olan duygusal okuryazarlık grup programının çocukların duygusal zekâ düzeylerini arttırdığı dikkat becerileri üzerinde ise etkili olmadığı saptanmıştır. Elde edilen bu sonuç değerlendirildiğinde özellikle dikkat becerilerini geliştirmek adına her oturumun başında dikkat etkinliklerine yer vermek bu tür çalışmaların etkililiğini arttırabilecek bir unsur olabilir. Ayrıca dikkat dağınıklığı olan çocuklardan oluşturulacak gruplarda yardımcı bir liderin çalışmaya dâhil olması ve grup üye sayısının 8 kişiyi geçmemesi çocukların çalışmaya daha fazla odaklanmalarına fayda sağlayabilir. Okullarda DEHB tanısı almış olan çocukların RAM ile işbirliği yapılarak 12 saate kadar destek eğitim odalarında kendi hızlarına uygun eğitim verilmesi dikkat becerilerini arttırmada olumlu katkı sağlayacaktır. 


\section{Kaynaklar}

Ak Sütlü, S. (2013). Sağllk çalışanlarında duygusal zekâ ve tükenmişlik ilişkisi. Yayınlanmamış yüksek lisans tezi. Beykent Üniversitesi Sosyal Bilimler Enstitüsü, İstanbul.

Arslanoğlu, A. (2008). The Relationship Between The Social Skills and Perceived Quality of Life of Boys with Attention Deficit/Hyperactivity Disorder-Predominantly HyperactiveImpulsive Subtype (ADHD-H). Yayınlanmamış Yüksek Lisans Tezi. Boğaziçi Üniversitesi, İstanbul.

Barkley, R. A. (2003). Issues in thediagnosis of attention-deficit/hyperactivity disorder in children. Brain \& Development, 25 (2), 77-83.

Bar-on, R. (2006). The Bar-On model of emotional-socialintelligence. Psicothema, 18, 13-25.

Befera M.S.,\& Barkley R.A. (1985). Hyperactive and normal girls and boys: Mother child interaction, parent psychiatric status and child psychopathology. J Child Psychol Psychiatry, 26, 439-452.

Bliss, L.S. \& McCabe, A. (2011). Educational implications of narrative discourse. Sandra Levey and Susan Polirstok (Ed.) Language Development (UnderstandingLangugeDiversity in theClassroom) içinde (209-224). USA: Sage.

Büyükaslan, A. (2015). Dikkat eksikliği hiperaktivite bozukluğu olan ilköğretim çocuklarında duygusal zekâ ile sosyal beceri bileşenlerinin değerlendirilmesi. Yayınlanmamış uzmanlık tezi. Marmara Üniversitesi Tip Fakültesi, İstanbul.

Büyüköztürk, Ş. (2007). Sosyal Bilimlerde Veri Analizi, Ankara: Pegema.

Cunningham C.E., \& Barkley R.A.,(1979). The interactions of normal and hyperactive children and their mothers in free play and structured tasks. Child Development., 50, 217-224.

Das, J.P., Naglieri, J.A. \& Kirby, J.R. (1994) Assessment of cognitive processes: The PASS theory of intelligence. Massachusetts: Allyn and Bacon A Division of Simon ve Schuster Inc.

Demirci, E. (2013). Dikkat eksikliği ve hiperaktivite bozukluğu olan erkek çocuk ve ergenlerin dürtüsellik, agresyon, empati becerileri ile serum oksitosin düzeylerinin ilişkisi. Yayınlanmamış uzmanlık tezi. Erciyes Üniversitesi Tip Fakültesi, Kayseri.

Ercan, E. S., \& Aydın, C. (2000). Dikkat Eksikliği Hiperaktivite Bozukluğu. İstanbul: Gendaş yayınları.

Ergin, D. Y., \& Özgürol, Ö. G. (2011). Bilimsel tutum ve duygusal zekâ arasindaki ilişki. Ankara: Siyasal Kitabevi.

Ergin,T., \& Köksal,A., (2007). “Bilişsel İşlevler ve Zekâ Arasındaki İlişkik”. 4.Uluslararası Çocuk İletişim Kongresi, İstanbul, Türkiye, 22-24 Ekim 2007, 131-139

Frankel, F., Myatt, R., Cantwell, D. P., \& Feinberg, D. T. (1997). Parent-assisted transfer of children's social skills training: effects on children with and without attention-deficit hyperactivity disorder. Journal of the American Academy of Child \& Adolescent Psychiatry, 36(8), 1056-1064.

Freshman, B. \& Rubino, L. (2002). Emotional intelligence: A core competency for health care administrators. The health care manager, 20(4), 1-9.

Goleman, D. (1996). Duygusal Zekâ.(Çev. B. S. Yüksel). İstanbul: Varlık yayınları.

Goleman, D. (2000). Leadership that gets results. Newhold ECS.

Göçet, E. (2006).Üniversite öğrencilerinin duygusal zekâ düzeyleri ile stresle başa çıkma tutumları arasındaki ilişki. Yayınlanmamış yüksek lisans tezi. Sakarya Üniversitesi Sosyal Bilimler Enstitüsü, Sakarya.

Gümütaş, F.(2011). Dikkat eksikliği hiperaktivite bozukluğu tanısı alan çocuk ve ergenlerde empatik yanıt verebilme,duygusal yüz ifadelerinin tanınması, empati-agresyon ilişkisi ve ilaç tedavisinin empati becerileri üzerine etkileri. Yayınlanmamış uzmanlık tezi. Marmara Üniversitesi Tip Fakültesi, İstanbul. 
Hafızoğlu, Ş. (2007). Ergenlerde duygusal zekâ, ruhsal uyum ve davranış problemleri arasındaki ilişki. Yayımlanmamış yüksek lisans tezi, Boğaziçi Üniversitesi Sosyal Bilimler Enstitüsü, İstanbul.

Hamarta, E., Deniz, M. E., \& Saltali, N. (2009). Attachment styles as a predictor of emotional intelligence. Educational Sciences: Theory and Practice, 9(1), 213-229.

Kaidar, I., Wiener, J. \& Tannock, R. (2003). The attributions of children with attention-deficit/ hyperactivity disorder for their problem behaviors. Journal of Attention Disorders. 6 (3),99-109.

Kanay, A. (2006). Dikkat eksikliği ve hiperaktivite bozukluğu olan 9-13 yaş grubu ilköğretim öğrencilerinin uyumsal davranışları, benlik kavramı ve akademik başarıları arasındaki ilişkiler. Dokuz Eylül Üniversitesi Eğitim Bilimleri Enstitüsü, İzmir.

Kaplan, F.B.(2002). Educating The Emotions: Emotional Intelligence Training for Earlychildhood Teachers and Caregivers. Yayınlanmamış Yüksek Lisans Tezi. Cardinal Stritch University, Milwaukee.

Konrad, S.,\& Hendl, C. (2001). Duygularla Güçlenmek: Duygusal Zekâ Sayesinde Başarıll Bir Hayat. İstanbul: Hayat Yayınları

Köksal, A. (2007).Üstün zekâlı çocuklarda duygusal zekâyı geliştirmeye dönük program geliştirme çalı̧ması. Yayınlanmamış doktora tezi. İstanbul Üniversitesi Sosyal Bilimler Enstitüsü, İstanbul.

Mayer, J. D., \& Salovey, P. (1995). Emotional intelligence and the construction and regulation of feelings. Applied and preventive psychology, 4(3), 197-208.

Nijmeijer, J. S., Minderaa, R. B., Buitelaar, J. K., Mulligan, A., Hartman, C. A., \& Hoekstra,P.J. (2008). Attentiondeficit/hyperactivity disorder and social dysfunctioning. Clinical Psychology review, 28(4), 692-708.

Özdemir,L.(2003).Yaratıcı Drama Dersini Duygusal Zekâ Gelişimine Etkisi.Yayınlanmamış Yüksek lisans tezi. Uludağ Üniversitesi Sosyal Bilimler Üniversitesi.Bursa

Özdemir, M. (2015). Eğitim fakültesi öğrencilerinin duygusal zekâları ile yaşam doyumlarının incelenmesi. Yayınlanmamış yüksek lisans tezi. Atatürk Üniversitesi Eğitim Bilimleri Enstitüsü, Erzurum.

Özmen, S. (2006). Dikkat toplama becerisini geliștirici etkinlikler. İlköğretim 1., 2. ve 3. simıf. Ankara: Anı Yayıncilik.

Öztürk, M. O. (2004). Ruh sağlığı ve bozuklukları. (9.baskı). Ankara: Nobel yayınları.

Öztürk Şahin, Ö., \& Tuğlu, C. (2010). Erişkin dikkat eksikliği hiperaktivite bozukluğu: nörobiyoloji, tanı sorunları ve klinik özellikler. Psikiyatride güncel yaklaşımlar, 2(1),75-116.

Roizen, N.J., Blondis, T.A., Irwin, M. \& Stein, M. (1994). Adaptive Functioning in Children with AttentionDeficit Hyperactivity Disorder. Arch Pediatr Adolesc Med. 148(11):1137-42.

Quinlan, M. (2007), “Organisational Restructuring/Downsizing, OHS Regulation and Worker Health and Well-being”, International Journal of Law and Psychiatry, 30, 385-399.

Shapiro, L.E. (1998). Yüksek EQ'lu Bir Çocuk Yetistirmek (Çev: U. Kartal) İstanbul: Varlık Yayınları

Saydanoğlu, T.(2011).Sağllk meslek lisesi öğrencilerinde saldrrganlık ve öfke düzeylerinin dikkat eksikliği ve hiperaktivite bozukluğu belirtileri ve benlik saygısı ile olan ilişkisinin araştırılması. Yayınlanmamış uzmanlık tezi. Kocaeli Üniversitesi Tip Fakültesi, Kocaeli.

Selçuk, Z.(2000). Dikkat eksikliği ve hiperaktif çocuklar. Ankara: Pegem akademi.

Soykan, A. A. (1991). Dikkat eksikliği ve hiperaktivite bozukluğu olan çocukların ruhsal ve organik yönden araştırılması. Yayımlanmamış çocuk psikiyatri uzmanlık tezi. Ankara Üniversitesi Tip Fakültesi, Ankara.

Steiner, C. (2003). Akıllı bir kalple duygusal okuryazarlık. M. Şahin (çev.). Ankara: Bilgi sistem yayıncılık.

Turgay, A. (1997). Gençlerde dikkat eksikliği ve hiperaktivite bozukluğu. Ege Psikiyatri Sürekli Yayınları, 2(3), 413-453. 
Tunca, Ö., Kılıç, G. (1981). Dikkat Geliştirme. Yaratıcı ve Görsel Etkinliklerle Uygulamalı. İstanbul: Ya-Pa Yayın.

Türe, F. Z. (2010). Dikkat eksikliği ve hiperaktivite bozukluğu olan çocukların (8-12 yaş) değişik anne tutumlarına göre benlik saygı düzeylerinin incelenmesi. Yayınlanmamış yüksek lisans tezi. Maltepe Üniversitesi Sosyal Bilimler Enstitüsü, İstanbul.

Ulutaş, İ. (2005). Anasınıfina devam eden altı yaş çocuklarımın duygusal zekâlarına duygusal zekâ eğitimin etkisinin incelenmesi. Yayınlanmamış doktora tezi. Gazi Üniversitesi Eğitim Bilimleri Enstitüsü, Ankara.

Yavuzer, H. (2000). Okul çağı çocukluğu. İstanbul: Remzi Kitabevi.

Yaşarsoy, E. (2006). Duygusal zekâ gelişim programının, eğitilebilir zihinsel engelli öğrencilerin davranış problemleri üzerindeki etkisinin incelenmesi. Yayımlanmamış Yüksek Lisans Tezi, Çukurova Üniversitesi Sosyal Bilimler Enstitüsü, Adana.

Yayc1, L. (2013). D2 dikkat testinin geçerlik ve güvenirlik çalışması. Kalem Eğitim ve İnsan Bilimleri Dergisi, $3(1), 43-80$.

Yeşilyaprak, B. (2002). Eğitimde Rehberlik Hizmetleri. Ankara: Nobel Yayınları.

Yurdakavuştu, Y. (2012). İlköğretim öğrencilerinde duygusal zekâ ve sosyal beceri düzeyleri. Yayınlanmamış yüksek lisans tezi. Dokuz eylül Üniversitesi Eğitim Bilimleri Enstitüsü, İzmir

Zampetakis, L. A., P. Beldekos \& V. S. Moustakis, (2009), "Day-today Entrepreneurship Within Organizations: The Role of Trait Emotional Intelligenceand Perceived Organizational Support", European Management Journal, 27, 165-175. 